CRITICAL REVIEW:

\title{
Inflasi dan Pertumbuhan Jangka Panjang : Sebuah Teori Baru Keynesian dan Bukti semiparametrik Lanjut
}

\author{
Anto Ariyanto ${ }^{1)}$ \\ ${ }^{1)}$ Staf pengajar Faperta Univ. Lancang Kuning
}

Tulisan ini bersumber dari jurnal Macroeconomic Dynamics, 16, 2012, 94-132. Judul yang review berjudul "Inflation and Growth in the Long Run: A New Keynesian Theory and Further Semiparametric Evidence " ditulis oleh Andrea Vaona dari University of Verona and Kiel Institute for the World Economy yang dipublikasikan pada tahun 2012.

\section{RINGKASAN JURNAL}

Makalah ini menawarkan sebuah model teoritis baru dan bukti empiris baru pada hubungan antara inflasi dan pertumbuhan. Pada bagian teoritis menunjukkan bahwa perubahan dalam tingkat inflasi dapat menghasilkan perubahan permanen dalam tingkat pertumbuhan output-meskipun model di sini diusulkan tidak mengandung ilusi uang, tidak ada kekakuan nominal permanen, dan tidak ada keberangkatan dari ekspektasi rasional.

Makalah ini melakukannya dengan memperluas model dari Graham dan Snower (2004) dari domain tingkat inflasi output ke inflasi pertumbuhan output. Sebagai konsekuensinya, menggabungkan model pertumbuhan endogen learning by doing Keynesian Baru dengan upah sulit, sehingga memungkinkan untuk mengeksplorasi bagaimana pengaruh inflasi terhadap pertumbuhan output terhubung tidak hanya untuk Efek langsung dari inflasi pada akumulasi modal, tetapi juga untuk orang-orang yang lewat tidak langsung melalui pasar tenaga kerja. Dalam konteks ini, ketika jumlah uang beredar tumbuh dengan friksi nominal sementara (dalam bentuk kontrak nominal kejut), penyesuaian nominal pernah memiliki kesempatan untuk sepenuhnya keluar bekerja sendiri. Dengan demikian, dalam konteks pertumbuhan endogen, perubahan dalam pertumbuhan uang mempengaruhi produk marjinal modal dan laju pertumbuhan ekonomi. 
Intuisi dasar untuk model yang diusulkan di sini dapat digambarkan sebagai berikut :

- Ketika kontrak upah nominal yang bergoyang, upah kontrak saat ini tergantung pada harga saat ini dan masa depan yang berlaku selama masa kontrak. Upah kontrak saat ini lebih dipengaruhi oleh harga saat ini dibandingkan dengan yang diharapkan harga masa depan, karena diskon waktu.

- Semakin tinggi tingkat pertumbuhan uang, kenaikan harga lebih cepat, dan upah kontrak lebih tertinggal tingkat harga saat ini. Dengan demikian rata-rata upah riil rendah selama periode kontrak. Akibatnya, tenaga kerja lebih banyak dituntut oleh perusahaan.

Dalam model pertumbuhan endogen ini, peningkatan input tenaga kerja meningkatkan marjinal produk dari modal, menyebabkan pertumbuhan ekonomi yang lebih cepat. Namun ada efek penyeimbang penting yaitu :

- Pertumbuhan uang dan akibat kenaikan inflasi, harga relatif menjadi lebih stabil, yaitu upah riil lebih bervariasi selama periode kontrak, karena upah nominal setiap kelompok konstan selama periode kontrak, sedangkan tingkat harga agregat meningkat secara bertahap.

- Volatilitas upah riil menyebabkan fluktuasi kerja, yaitu, "peredaran kerja". Karena semakin berkurang tenaga kerja, ini tidak efisien, mengarah ke penurunan produk marjinal modal dan pertumbuhan output.

Pengaruh ini menyiratkan hubungan negatif jangka panjang antara inflasi dan pertumbuhan output. Dalam makalah ini menunjukkan dalam contoh numerik, bahwa ketika elastisitas antar waktu substitusi waktu kerja diatur ke nol, efek diskon yang dominan pada tingkat pertumbuhan uang rendah, sedangkan efek peredaran kerja yang dominan pada tingkat pertumbuhan uang tinggi. Dengan implikasi, hubungan jangka panjang antara inflasi dan pertumbuhan output mundur artinya, pertumbuhan meningkat dengan inflasi dengan tarif rendah, tapi jatuh dengan inflasi pada tingkat inflasi yang tinggi. Namun, memungkinkan untuk elastisitas antar waktu positif substitusi waktu kerja, inflasi memiliki dampak negatif pada pertumbuhan, karena rumah tangga,memiliki preferensi yang lebih besar untuk memperlancar pasokan tenaga kerja, menanggapi kenaikan pertumbuhan uang yang memerlukan tenaga kerja 
yang lebih beredar dengan meningkatkan upah mereka, mengurangi lapangan kerja dan pertumbuhan output.

Akhirnya, endogenizing panjang dari kontrak kerja mereduksi kekuatan pengaruh inflasi terhadap pertumbuhan, namun dengan adanya biaya tetap untuk upah yang diatur ulang, efek negatif inflasi terhadap pertumbuhan tidak hilang. Ini karena rumah tangga dapat mengurangi peredaran tenaga kerja dengan membayar biaya pengaturan ulang upah lebih sering. Jadi mereka memilih fleksibilitas upah hanya untuk tingkat biaya rendah. Implikasi kesejahteraan dari parameterisasi model yang berbeda juga dibahas tulisan ini.

Bagian empiris dari tulisan ini terutama didasarkan pada metode estimasi semiparametrik yang diterapkan pada set data antar negara/time-series. Namun, mengikuti strategi penelitian yang berbeda. Tulisan ini pertama kali menggunakan kriteria seleksi model untuk berbagai pendekatan estimasi deret kuasa semiparametrik. Kemudian memeriksa apakah hasil memiliki bias endogenitas dan melakukan berbagai tes stabilitas subsampel. Akhirnya, dengan mengadopsi estimator kernel Nadaraya-Watson, menggunakan satu linear local dengan variabel window width. Dalam tulisan ini menemukan bahwa inflasi yang lebih tinggi hanya merugikan pertumbuhan riil ekonomi. Hasil empiris yang diperoleh membantu dalam memilih kalibrasi model teoritis yang disukai.

\section{LITERATUR REVIEW}

Dengan pengecualian dari beberapa studi terbaru, teori literatur menyatakan bahwa model yang dihasilkan dimana inflasi memiliki dampak negatif pada pertumbuhan. Salah satu studi teoritis pertama mengenai inflasi dan output yaitu Tobin (1965), yang menyatakan inflasi menguntungkan tingkat output karena menurunkan tingkat bunga dan karenanya opportunity cost untuk berinvestasi. Ini meningkatkan rasio modal tenaga kerja output. Stockman (1981) menunjukkan kemungkinan adanya efek Tobin terbalik, dimana kenaikan tingkat inflasi menyebabkan persediaan modal menurun.

Baru-baru ini, beberapa literatur telah bergeser dari tingkat output ke tingkat pertumbuhan output dan dari model Solow untuk pertumbuhan endogen. Gillman dan Kejak 
(2005) mengusulkan untuk membedakan antara model modal fisik dilabel sebagai Ak, modal manusia dilabel sebagai Ah, dan model gabungan manusia dan modal fisik. Hasilnya diperoleh beberapa kontribusi yang menghasilkan efek inflasi pertumbuhan jangka panjang tidak signifikan, seperti model Ak Irlandia (1994) dan Dotsey dan Sarte (2000) dan model gabungan Chari et al. (1996). Kontribusi lainnya telah menghasilkan inflasi negatif dan efek pertumbuhan signifikan, seperti model Ak dari Haslag (1998) dan Gillman dan Kejak (2004), model Ah dari Gillman et al. (1999), dan model gabungan Gomme (1993) dan Gillman dan Kejak (2002, 2005b). Gillman dan Kejak (2005a) mengusulkan model yang sebagian besar model lebih maju dari sebelumnya. Hasilnya mereka adalah inflasi Ak model bekerja sebagai pajak atas modal fisik menyiratkan efek negative, Tobin (1965), sedangkan pada inflasi Ah model yang bekerja sebagai pajak atas modal manusia, menyiratkan efek positif, Tobin (1965). Akhirnya, dalam model gabungan, inflasi bekerja lebih pada pajak atas modal manusia dari pada modal fisik, menyiratkan efek positif, Tobin(1965). Dalam model biaya berkaitan dengan transaksi uang, Zhang (2000) menunjukkan bahwa peningkatan pertumbuhan uang mengarah ke input produksi steady-state, konsumsi, dan keseimbangan uang riil rendah. Akhirnya, Gylfason dan Herbertsson (2001) mengusulkan untuk memasukkan keseimbangan uang riil ke dalam fungsi produksi, sebagai proksi dari pengaruh krisis keuangan pada produksi [Raja dan Levine (1993), Levine (1997); Gylfasondan Zoega (2006)], dan mereka menemukan efek negatif inflasi terhadap pertumbuhan melalui tiga saluran yaitu menurunkan tingkat bunga riil dan tabungan, mengurangi efisiensi dengan memberikan ganjalan antara kembali ke riil dan modal keuangan, dan, akhirnya mengurangi krisis keuangan, tetapi merugikan output.

Wang dan Yip (1992), menyatakan bahwa inflasi berhubungan negatif dengan pertumbuhan, karena penurunan dalam keseimbangan uang riil yang timbul dari kenaikan tingkat pertumbuhan moneter menimbulkan waktu transaksi dan biaya transaksi. Mino dan Shibata (1995), menyatakan bahwa tumpang tindih-generasi, menunjukkan bahwa inflasi mungkin memiliki dampak redistributif dari satu generasi ke generasi lain dan akumulasi modal. Bonatti (2002a, 2002b) berpendapat bahwa, ketika beberapa jalur pertumbuhan seimbang dalam ekonomi non moneter, penargetan inflasi tidak dapat mengatasi ketidakpastian, sedangkan aturan pertumbuhan fixed-moneter dapat melakukannya, dan juga menentukan jalur pertumbuhan ekonomi. Selain itu, pembatasan kebijakan moneter dapat memilih jalur pertumbuhan yang lebih rendah dari pada yang lebih luas. 
Paal dan Smith (2001), menyatakan bahwa hubungan antara pertumbuhan uang dan real pertumbuhan terbukti ditandai dengan ambang. Pada tingkat uang pertumbuhan yang rendah, bank melihat biaya peluang kecil dalam cadangan menahan bukan pinjaman dana untuk investasi. Pertumbuhan uang meningkat, tingkat bunga nominal naik juga, meningkatkan biaya kesempatan memegang cadangan dan memacu pinjaman dan investasi serta pertumbuhan. Ketika tingkat bunga nominal tumbuh melampaui ambang batas tertentu, penjatahan kredit buruk mempengaruhi pinjaman, mengurangi modal akumulasi dan pertumbuhan. Juga, Bose (2002), menyatakan berkaitan dengan dampak inflasi pada pertumbuhan melewati pasar kredit. Makalah ini berpendapat bahwa,pada informasi asimetris antara pemberi pinjaman dan peminjam, mungkin ada dua rezim pinjaman. Pada yang pertama, peminjam tinggi dan berisiko rendah dipisahkan oleh penjatahan kredit (penjatahan rezim). Dalam satu yang terakhir, pemisahan terjadi melalui skrining (rezim screening). Kenaikan tingkat inflasi meningkatkan biaya penyaringan atau kejadian penjatahan kredit, atau bahkan mungkin menghasilkan perubahan dari skrining terhadap rezim penjatahan. Semua tiga efek yang berbahaya bagi pertumbuhan. Di sisi lain, Funk dan Kromen $(2005,2006)$ meneliti sambungan antara inflasi dan pertumbuhan dalam kerangka Schumpeter dengan Harga kekakuan jangka pendek. Mereka juga menemukan lokus inflasi pertumbuhan berbentuk punuk, karena efek distorsi yang dihasilkan oleh inflasi pada insentif untuk berinovasi. Hal ini dimungkinkan untuk menyimpulkan bahwa literatur teoritis telah difokuskan pada efek inflasi pada pertumbuhan melewati akumulasi baik manusia atau fisik modal, melalui pasar kredit atau melalui pasar produk. Penelitian ini,sebaliknya, berkaitan dengan pengaruh inflasi terhadap pertumbuhan riil melewati tenaga kerjapasar dengan adanya upah mengejutkan. Selanjutnya, penelitian ini memberikan berbagai wawasan perhubungan inflasi pertumbuhan dibanding Funk dan Kromen $(2005,2006)$ menggunakan-learning by doing Model dan bukan kerangka Schumpeter, wage staggering dan bukan harga-kejut, dan lebih penting lagi, penawaran tenaga kerja tidak eksogen, tetapi ditentukan oleh perilaku mengoptimalkan agen ekonomi. Temple (2000) menawarkan review yang lebih luas dari literatur teoritis. 


\section{TANGGAPAN}

New Keynesian economics merupakan school of thought dalam ekonomi makro modern yang berkembang dari ide John Maynard Keynes. Keynes menulis buku The Theory of Employment, Interest, and Money tahun 1930an, dan pengaruh pemikirannya sangat kuat di kalangan akademisi dan pembuat kebijakan sampai dengan tahun 1960. Namun demikian pada tahun 1970-an, ekonom New Classical seperti Robert Lucas, Thomas J. Sargent, dan Robert Barro mempertanyakan pemikiran dari revolusi Keynesian. Label "New Keynesian" mengambarkan para ekonom (pada tahun 1980-an) yang merespon dari kritik new classical dengan melakukan penyesuaian aliran original Keynesian.

Pokok ketidaksepakatan antara ekonom new classical dan new Keynesian adalah seberapa cepat wages dan price melakukan penyesuaian. Para ekonom new classical membangun teori ekonomi makro dengan mengasumsikan bahwa wages dan price adalah fleksibel. Mereka percaya bahwa pada pasar terjadi "market clearing" -keseimbangan supply dan demand- dengan penyesuaian harga yang dengan cepat. Para ekonom New Keynesian percaya bahwa model "market clearing" tidak dapat menjelaskan fluktuasi ekonomi dalam jangka pendek, dan mereka menawarkan model dengan "sticky" wages dan prices. Teori new Keynesian mengacu pada stickiness of wages and prices untuk menjelaskan mengapa terjadi adanya involuntary unemployment dan mengapa kebijakan moneter mempunyai pengaruh yang kuat aktivitas ekonomi.

Tradisi yang panjang dalam ekonomi makro (termasuk kedua perspektif Keynesian dan monetarist) menekankan bahwa kebijakan moneter akan mempengaruhi orang bekerja dan produksi dalam jangka pendek, sebab harga akan merepon sluggishly adanya perubahan dalam money supply. Menurut pandangan ini, jika money supply menurun, orang-orang akan mengurangi pembelanjaan uang dan permintaan barang akan menurun. Karena harga dan upah adalah inflexible dan tidak segera menurun, maka penurunan pengeluaran masyarakat akan menyebabkan penurunan penurunan produksi dan layoffs pekerja. Ekonom New Classical mengkritisi tardisi isi sebab penjelasan teoritis tentang perilaku penyesuaian harga dan upah yang lambat kurang masuk akal. Banyak penelitian New Keynesian berupaya untuk mengatasi kekurangan ini. 
Pengaruh kebijakan moneter terhadap output dan harga merupakan perdebatan yang panjang baik berkaitan segi teoritis maupun empiris. Hal itu tidak terlepas dari perkembangan aliran pemikiran ekonomi dari mulai clasical, neo-clasical, neo-clasical synthesis, new clasical dan new keynesian.

Dalam pandangan Klasik bahwa uang hanya berpengaruh terhadap harga dan tidak terhadap output. Dengan mengunakan analisa general ekulibrium yang memasukan uang ke dalam model menghasilkan money neutrality yang menunjukan uang tidak berpengaruh terhadap keseimbangan pasar.

Di sisi lain, pandangan Keynesian bahwa uang berpengaruh terhadap harga dan output karena adanya rigiditas harga dan penganguran tak sukarela (involuntary unemployment). Pandangan tersebut dimodelkan dengan IS-LM untuk keseimbangan pasar uang dan pasar barang (aggregate demand) serta dan adanya disekuilibrium pasar tenaga kerja pada sektor perusahaan (aggregate supply).

Dalam model Neoclassical Synthesis menjelaskan terjadinya rigiditas harga dan upah karena adanya asumsi perilaku perusahaan dalam menentukan harga yaitu secara mark-up dari upah. Oleh karena itu, walaupun real wage adalah flexible, namun karena pricing behaviour dilakukan secara mark-up maka terjadi rigiditas harga dan upah sehingga money supply berpengaruh terhadap real output dan harga.

Nilai ekpektasi agen ekonomi untuk menyikapi ketidakpastian yang akan datang sangat mempengaruhi dalam makroekonomi. Dua hipotesis ekpektasi yang penting dalam ekonomi adalah adaptive expectation dan rational expectation. Milton Freidman (1957) memperkenalkan adaptive expectation yaitu bahwa ekpektasi agen ekonomi dibentuk oleh observasi inflasi saat ini. Fenomena Phillip curve ditantang oleh Friedman yang mengemukakan argumen bahwa hanya unanticipated inflation saja yang berpengaruh terhadap unemployment. Ekonom ini menekankan pentingnya ekpektasi pada aggregate supply sehingga memperbaiki Philip curve menjadi expectation-augmented Phillip curve.

New Keynesian merupakan perbaikan dari Neo-clasical synthesis dengan memasukan aspek rational expectation serta memperkuat landasan mikroekonomi. Namun demikian, ekonom Keynesian masih tetap mempercayai adanya imperfect market dan nominal rigidity dapat 
mengakibatkan fluktuasi (deviasi) output dari natural output. Fischer (1977) dan Taylor (1980) berpendapat bahwa terjadinya nominal rigity disebabkan adanya staggering of wage and price dicisions oleh perusahaan-perusahaan. Adanya Staggering dalam upah dan harga tersebut mengakibatkan penyesuaian price level secara perlahan-lahan sehingga perubahan dalam aggregate demand berdampak pada fluktuasi output.

Dalam sintesa New Keynesian, para ekonom [Gali dan Gertler (1999) dan Gali et al. (2001); Roberts (2001); Fuhrer (1997); Linde (2005)] telah mempelajari bagaimana membangun model yang sederhana, saling terkait, dan struktural yang dapat menjelaskan mekanisme transmisi moneter khususnya transmisi melalui interest rate dan pengaruhnya terhadap inflasi dan output. Model tersebut dikenal sebagai model New Keynesian Small Macroeconomics (NKSM) dengan pendekatan dynamic stochastic general equlibrium yang mengandung aspek ekpektasi dan juga solid dengan landasan mikroekonomi. Model sederhana tersebut mengandung aggregate demand, price-setting (Phillips) curve, dan fungsi reaksi dari suatu kebijakan suku bunga terhadap output dan inflasi. Model ini mewujudkan prinsip dasar dari peran bijakan moneter melalui instrumen suku bunga nominal untuk stabilisasi inflasi.

Ekonom New Keynesian sering mengarah pada teori dari apa yang mereka sebut efisiensi upah untuk menjelaskan mengapa mekanisme market-clearing ini gagal. Teori ini berpegang pada upah yang tinggi membuat pekerja lebih produktif. Pengaruh upah pada efisiensi pekerja dapat dijelaskan pada kegagalan perusahaan untuk memotong upah meskipun terjadi kelebihan pasokan tenaga kerja. Walaupun penurunan upah akan mengurangi tagihan perusahaan, hal itu juga akn menyebabkan produktifitas pekerja dan dan keuntungan perusahaan akan turun.

Ada berbagai teori tentang bagaimana upah mempengaruhi produktivitas pekerja. Efisiensi upah. Teori pertama efesiensi-upah berpendapat bahwa tingginya upah buruh akan mengurangi turnover pekerja. Pekerja keluar dari perusahaan dengan berbagai alasan yaitu: untuk menerima posisi yang lebih baik di perusahaan lain, untuk mengubah karir, atau untuk berpindah ke negara lain. Semakin banyak perusahaan membayar para pekerja, semakin besar insentif mereka untuk tinggal dengan perusahaan. Dengan membayar upah yang tinggi, perusahaan akan mengurangi frekuensi pekerja yang keluar dari perusahaan, sehingga akan mengurangi waktu yang dihabiskan untuk perekrutan dan pelatihan pekerja baru. 
Teori kedua efisiensi-upah berpendapat bahwa rata-rata kualitas tenaga kerja dari sebuah perusahaan tergantung pada itu upah yang dibayarkan para karyawannya. Jika perusahaan mengurangi upah, karyawan terbaik mungkin akan mengambil pekerjaan di tempat lain, dan perusahaan dtinggal dengan karyawan kurang produktif yang memiliki alternatif kesempatan lebih sedikit. Dengan membayar upah di atas tingkat keseimbangan, maka perusahaan ini menghindari adverse selection, meningkatkan kualitas rata-rata dari tenaga kerja, dan dengan demikian meningkatkan produktivitas.

Teori ketiga efisiensi-upah berpendapat bahwa upah yang tinggi akan meningkatkan effort pekerja. Teori ini memposisikan bahwa perusahaan tidak dapat memantau dengan sempurna work effort karyawannya dan bahwa karyawan yang harus memutuskan cara sendiri untuk bekerja keras. Pekerja dapat memilih untuk bekerja keras, atau mereka dapat memilih untuk mangkir dan risiko tertangkap dan mendapatkan PHK. Perusahaan dapat meningkatkan work effort karyawan dengan membayar upah yang tinggi. Semakin tinggi upah, semakin besar adalah biaya pekerja untuk PHK. Dengan membayar upah lebih tinggi, perusahaan menekan beberapa karyawannya untuk tidak mangkir, dan dengan demikian akan meningkatkan produktivitas mereka.

Intinya adalah pandangan bahwa perekonomian merupakan sistem dinamis keseimbangan umum (dynamic general equilibrium system) yang mempunyai deviasi dengan alokasi yang efisien sumber daya dalam jangka pendek karena adanya sticky price dan mungkin berbagai market imperfections lainnya. Dalam banyak hal, sintesis baru membentuk intelektual dasar untuk analisis kebijakan moneter pada Federal Reserve dan bank sentral di seluruh dunia.

Karena ekonomi New Keynesian adalah school of thought mengenai teori ekonomi makro, para penganutnya tidak harus mempunyai satu pandangan tentang kebijakan ekonomi. Pada tingkat yang lebih luas, ekonomi New Keynesian menyarankan -berbeda dengan classical theories- resesi adalah keberangkatan dari normal efisien fungsi dari pasar. Unsur yang New Keynesian economic -seperti menu cost, staggered price, coordination failures, and efficiency wages- mencerminkan penyimpangan yang substansial dari asumsi ekonomi klasik, yang menyediakan dasar intelektualitas para ekonom "yang biasa dengan justifikasi dari laissez-faire". Dalam teori New Keynesian recessions disebabkan oleh perekonomian kegagalan pasar yang lebar. Dengan demikian, ekonomi New Keynesian menyediakan alasan bagi intervensi 
pemerintah dalam perekonomian, seperti countercyclical moneter atau kebijakan fiskal. Bagian ini dari ekonomi New Keynesian telah dimasukkan ke dalam sintesis baru yang muncul di antara macroeconomists. Apakah policymaker harus intervensi dalam prakteknya, bagaimanapun, hal ini merupakan sebuah pertanyaan yang lebih sulit yang mana dipengaruhi berbagai politik dan juga keputusan ekonomi.

\section{KESIMPULAN}

Makalah ini memperluas hasil literatur Keynesian Baru dengan upah kejut dari hubungan antara inflasi dan tingkat output ke inflasi pertumbuhan. Dengan cara ini mungkin dapat menjelajahi bagaimana inflasi mempengaruhi pertumbuhan melewati pasar tenaga kerja, bukan modal, kredit, atau produk pasar. Untuk elastisitas antar waktu substitusi waktu kerja lebih besar dari nol. Inflasi memiliki dampak riil yang cukup besar, yaitu merugikan pertumbuhan ekonomi dan mengurangi kesejahteraan ekonomi. Dengan asumsi panjang endogen dari kontrak kerja tidak umum untuk uang supernetralitas. Di hadapan biaya tetap untuk mengubah upah, upah agen lebih mengejutkan untuk upah fleksibilitas kecuali inflasi tinggi-seberapa tinggi tergantung pada besarnya biaya tetap. Hasil empiris mengkonfirmasi bahwa inflasi memiliki dampak negatif terhadap pertumbuhan, dan tidak ada ambang tingkat inflasi ditemukan. Makalah ini berpendapat bahwa konsisten dengan model teoritis dengan preferensi umum.

\section{DAFTAR PUSTAKA}

Altissimo, Filippo, Michael Ehrmann, and Frank R. Smets (2006) Inflation Persistence and Price Setting Behaviour in the Euro Area. Occasional Paper 46, European Central Bank.

Ascari, Guido (2003) Price/wage staggering and persistence: A unifying framework. Journal of Economic Surveys 17, 511-40.

Barro, Robert J. (1995) Inflation and Economic Growth. Working paper 5326, National Bureau of Economic Research.

Benigno, Pierpaolo (2004) Optimal monetary policy in a currency area. Journal of International Economics 63, 293-320.

Bose, Niloy (2002) Inflation, the credit market and economic growth. Oxford Economic Papers $54,412-434$. 
Boyd, John H., Ross Levine, and Bruce Smith (2001) Inflation and financial market performance. Journal of Monetary Economics 47, 221-248.

Bruno, Michael and William Easterly (1998) Inflation crises and long-run growth. Journal of Monetary Economics 41, 3-26.

Bullard, James (1999) Testing long-run monetary neutrality propositions: Lessons from the recent research. Federal Reserve Bank of St.Louis Review 81, 57-77.

Burdekin, Richard C. K., Arthur T. Denzau, Manfred W. Keil, Thitithep Sitthiyot, and Thomas D. Willet (2004) When does inflation hurt economic growth? Different non-linearities for different countries. Journal of Macroeconomics 26, 519-532.

Christopoulos, Dimitri and Efthymios G. Tsionas (2005) Productivity growth and inflation in Europe: Evidence from panel cointegration tests. Empirical Economics 30, 137-150.

Cooley, Thomas F. and Edward Prescott (1995) Economic growth and business cycles. In Thomas F.

Dotsey, Michael and Pierre D. Sarte (2000) Inflation, uncertainty and growth in a cash-inadvance economy. Journal of Monetary Economics 45, 631-655.

Fan, Jianqing and Irene Gijbels (1992) Variable bandwidth and local linear regression smoothers. Annals of Statistics 20, 2008-2036.

Fischer, Stanley (1993) The role of macroeconomic factors in growth. Journal of Monetary Economics 41, 485-512.

Funk, Peter and Bettina Kromen (2005) Inflation and Innovation Driven Growth. Working Paper Series in Economics 16, University of Cologne.

Ghosh, Atish R. and Steven Phillips (1998) Inflation, Disinflation and Growth. Working paper 98/68, International Monetary Fund.

Gillman, Max, Mark N. Harris, and Laszlo Matyas (2004) Inflation and growth: Explaining the negative effect. Empirical Economics 29, 149-167.

Gillman, Max and Michal Kejak (2005a) Contrasting models of the effect of inflation on growth. Journal of Economic Surveys 19, 113-136.

Gillman, Max and Michal Kejak (2005b) Inflation and balanced-path growth with alternative payment mechanisms. Economic Journal 115, 1-25.

Gillman, Max, Michal Kejak, and Akos Valentinyi (1999) Inflation, Growth, and Credit Services. Transition Economics Series 13, Institute of Advanced Studies, Vienna. 
Gomme, Paul (1993) Money and growth: Revisited. Journal of Monetary Economics 32, $51-77$.

Graham, Liam and Dennis Snower (2008) Hyperbolic discounting and the Phillips curve. Journal of Money, Credit and Banking 40, 427-448.

Guerrero, Federico (2006) Does inflation cause poor long-term growth performance? Japan and the World Economy 18, 72-89.

Gylfason, Thorvaldur (1991) Inflation, growth and external debt: A view of the landscape. World Economy 14, 279-297.

Haslag, Joseph H. (1998) Monetary policy, banking and growth. Economic Inquiry 36, 439450.

Haslag, Joseph and Jahyeong Koo (1999) Financial Repression, Financial Development and Economic Growth. Working paper 99-02, Federal Reserve Bank of Atlanta.

Heijdra, Ben J. and Frederick Van der Ploeg (2002) The Foundations of Modern Macroeconomics. Oxford, UK: Oxford University Press.

Huang, Kevin X. D. and Zheng Liu (2002) Staggered price-setting, staggered wage-setting, and business cycle persistence. Journal of Monetary Economics 49, 405-433.

Ireland, Peter (1994) Money and growth: An alternative approach. American Economic Review $55,1-14$.

Jones, Charles I. (1995) Time series tests of endogenous growth models. Quarterly Journal of Economics 110, 495-525.

Judson, Ruth and Athanasios Orphanides (1999) Inflation, volatility and growth. International Finance 2, 117-138.

Kahn, Mohsin S. and Semlali A. Senhadji (2001) Threshold effects in the relationship between inflation and growth. IMF Staff Papers 48, 1-21.

Kim, Sung and Thomas D. Willett (2000) Is the negative correlation between inflation and growth real? An analysis of the effects of the oil supply shocks. Applied Economics Letters 7, 141-147.

King, Robert G. and Ross Levine (1993) Finance and growth: Schumpeter might be right. Quarterly Journal of Economics 108, 717-737.

Levine, Ross (1997) Financial development and economic growth: Views and agenda. Journal of Economic Literature 35, 688-726. 
Li, Qi and Jeffrey S. Racine (2007) Nonparametric Econometrics. Princeton, NJ: Princeton University Press.

Minford, Patrick and David Peel (2004) Calvo Contracts: A Critique. Discussion Papers 4288, Centre for Economic Policy Research, London.

Mino, Kazuo and Akihisa Shibata (1995) Monetary policy, overlapping generation, and patterns of growth. Economica 62, 179-194.

Paal, Beatrix and Bruce Smith (2001) The Sub-Optimality of the Friedman Rule and the Optimum Quantity of Money. IEHAS Discussion Paper 0113, Institute of Economics, Hungarian Academy of Sciences, Budapest.

Pagan, Adrian and Aman Ullah (1999) Nonparametric Econometrics. Cambridge, UK: Cambridge University Press.

Pollin, Robert and Andong Zhu (2006) Inflation and economic growth: A cross-country nonlinear analysis. Journal of Post-Keynesian Economics 28, 593-614.

Ramsey, James B. (1969) Test for specification errors in classical linear least squares regression analysis. Journal of the Royal Statistical Society (Series B) 31, 350-371.

Sarel, Michael (1996) Nonlinear effects of inflation on economic growth. IMF Staff Papers 43, 199-215.

Stockman, Alan C. (1981) Anticipated inflation and the capital stock in a cash-in-advance economy. Journal of Monetary Economics 8, 387-393.

Temple, Jonathan (2000) Inflation and growth: Stories short and tall. Journal of Economic Surveys 14, 395-426.

Thirlwall, Anthony P. and Christopher A. Barton (1971) Inflation and growth: The international evidence. Banca Nazionale del Lavoro Quarterly Review 98, 263-275.

Tobin, James (1965) Money and economic growth. Econometrica 33, 671-684.

Vaona, Andrea and Stefano Schiavo (2007) Non-parametric and semiparametric evidence on the longrun effects of inflation on growth. Economics Letters 94, 452-458.

Wang, Ping and Chong K. Yip (1992) Alternative approaches to money and growth. Journal of Money, Credit and Banking 24, 553-562.

Wolff, Edward N. (2003) What's behind the rise in profitability in the US in the 1980s and in the 1990s? Cambridge Journal of Economics 27, 479-499. 
Woodford, Michael (1998) Doing without money: Controlling inflation in a post-monetary world. Review of Economic Dynamics 1, 173-219.

Zhang, Junxi (2000) Inflation and growth: Pecuniary transactions costs and qualitative equivalence. Journal of Money Credit and Banking 32, 1-12. 